\title{
TWO NEW POPULATIONS OF THE EUROPEAN MUDMINNOW, UMBRA KRAMERI (ACTINOPTERYGII: ESOCIFORMES: UMBRIDAE), IN SOUTH-WESTERN ROMANIA WITH THE FIRST RECORD IN THE BANAT REGION
}

\author{
Severus-D. COVACIU-MARCOV ${ }^{1}{ }^{*}$, Diana CUPŞA ${ }^{1}$, Ilie C. TELCEAN ${ }^{1}$, \\ István SAS-KOVÁCS ${ }^{1}$, and Sára FERENȚI ${ }^{1,2}$ \\ ' Department of Biology, Faculty of Sciences, University of Oradea, Oradea, Romania \\ “"Iosif Vulcan” National College, Oradea, Romania
}

Covaciu-Marcov S.-D., Cupșa D., Telcean I.C., Sas-Kovács I., Ferenți S. 2018. Two new populations of the European mudminnow, Umbra krameri (Actinopterygii: Esociformes: Umbridae), in south-western Romania with the first record in the Banat region. Acta Ichthyol. Piscat. 48 (3): 251-255.

\begin{abstract}
Two new populations of the European mudminnow, Umbra krameri Walbaum, 1792, were encountered in Banat and Oltenia regions, south-western Romania, within 2014-2017. The mudminnows were captured with a hand net used normally for frogs. This is the first record of this species for Banat. In Oltenia U. krameri was encountered in a region where it was considered extinct. In both areas $U$. krameri was present in its characteristic habitats, i.e., small water bodies with dense aquatic vegetation. Umbra krameri is subject to human pressure in both areas, but this pressure is more severe in Banat, where the agriculture is more intensive. The rare findings of the species in southern Romania are probably due to unsuitable searching methods often used in surveys, i.e., conducted only in large, but unsuitable aquatic habitats, and using classical ichthyological methods, such as electrofishing.
\end{abstract}

Keywords: European mudminnow, Romania, small habitats, distribution, relict

\section{INTRODUCTION}

Recent studies revealed a high genetic diversity of populations of the European mudminnow, Umbra krameri Walbaum, 1792 (see Marić et al. 2015, 2017, Takács et al. 2015). Different population groups should be treated as distinct evolutionarily significant units or conservation units (Takács et al. 2015, Marić et al. 2017), which is an important fact for this endangered species (Povž 1995). Umbra krameri has a small distribution range in the Danube and Dniester drainage basins (Wanzenböck 1995, Kottelat and Freyhof 2007, Kuehne and Olden 2014), but it disappeared from the majority of its initial area according to Kottelat and Freyhof (2007). Umbra krameri is also present in Romania, a country situated in the Danube River basin (Mândruț 2006). In Romania, $U$. krameri was recorded in some localities in the plain areas situated outside the Carpathians, in north-western Romania, the Danube Delta, Danube floodplain, and Romanian Moldova (Bănărescu et al. 1995, Bănărescu 2005, Oţel 2007, Wilhelm and Ardelean 2009, Telcean et al. 2014). Umbra krameri was not encountered in the Banat region in south-western Romania, although apparently favourable habitats are present in the region (Bănărescu et al. 1995). The majority of distribution records in
Romania are outdated (Bănărescu et al. 1995). Moreover, in southern Romania, recent studies failed in identifying this species, even in regions where it was mentioned in the past (Imecs and Nagy 2013), but also in other areas situated within its known distribution range (Năstase and Oțel 2016). In recent years, U. krameri disappeared from many habitats following human interventions, both in Romania (Bănărescu 2005, Wilhelm and Ardelean 2009) and Hungary (Tatár et al. 2017). Under such circumstances, identifying any new population of this endangered species is very important.

\section{MATERIAL AND METHODS}

Field surveys were made sporadically between within 2014-2017, in the plain areas of south-western Romania (Banat and Oltenia regions). In each year we made several field trips from March to October. Our research objective was not fishes, but amphibians and reptiles. Nevertheless, during those field studies, we sometimes identified fish species in typical amphibian habitats (Covaciu-Marcov et al. 2017a, 2017b). Amphibians (especially newts) were searched and captured in small aquatic habitats, with the help of a net with a round opening, mounted on a $1.5 \mathrm{~m}$ long metal handle. Because of its length, but also because

* Correspondence: Dr. Severus-Daniel Covaciu-Marcov, Universitatea din Oradea, Facultatea de Ştiințe, Departamentul Biologie, Str. Universităţii, nr. 1, Oradea 410087, România, e-mail: (SDCM) severcovaciu1@gmail.com, (DC) cupsa2007@yahoo.com, (ICT) itelcean@gmail.com, (ISK) sas.steve@gmail.com, (SF)ferenti.sara@gmail.com. 
of the small size of the investigated aquatic habitats, this net was usually operated from the shore. The captured animals were set free in their habitats after they were determined and eventually photographed. Because we did not have an aquarium with us each time, some photos were made in a plastic bottle cut in half. The determination took place in the field, taking only few seconds. The fish were not measured, because we did not want to harm them.

\section{RESULTS}

Between 2014 and 2017 two Umbra krameri populations were discovered in two localities within southwestern Romania, one in the Banat region and one in the Oltenia region (Fig. 1). Both localities are situated in plain areas. In Banat, U. krameri was identified on 8 March 2014, near Obad village, approximately $25 \mathrm{~km}$ south-west from Timişoara city. The habitat close to Obad is situated in the Timiş River basin, approximately $15 \mathrm{~km}$ from the main river course. It is a channel measuring approximately $1 \mathrm{~m}$ width and $0.5 \mathrm{~m}$ depth. The channel, which was probably a natural stream, is situated $1 \mathrm{~m}$ below the surrounding agricultural areas. It has very rich aquatic vegetation, a lot of water mint and reeds. Besides U. krameri, we also found Misgurnus fossilis (Linnaeus, 1758) as the only accompanying fish species. Among amphibians, Triturus dobrogicus, Lissotriton vulgaris, Bombina bombina, and Pelophylax ridibundus were present. We captured mostly U. krameri juveniles, but also adults, even one of approximately $8 \mathrm{~cm}$ length. On a channel length of only 30 $\mathrm{m}$, we captured 12 individuals. The habitat was revisited on 5 March 2017, when we encountered two individuals. In Oltenia, U. krameri was found on 1 October 2016 in the lower reaches of the Jiu River, between villages Rojiște and Tâmburești. The location was situated halfway between Craiova city and Bechet town, approximately $30 \mathrm{~km}$ from both. The mudminnows were present in a canal situated in the Jiu River floodplain also containing the Jiet rivulet, which runs close to the limit of this floodplain along the terraces of its eastern border. The entire area is crossed by numerous canals and small rivulets characterized by slow flow and rich vegetation. In such a habitat we captured two U. krameri individuals, one juvenile of approximately three $\mathrm{cm}$ in length and one adult of almost eight $\mathrm{cm}$ in length (Fig. 2). The habitat had a lot of vegetation both in the water and on the shores and only few open water areas, being surrounded by pastures. The substratum consisted of sand and gravel. Fish were captured from the vegetation. Besides Umbra krameri, we recorded also other fish species such as Carassius carassius (Linnaeus, 1758), Gobio sp., and Cobitis sp. Among amphibians we encountered numerous large Pelophylax ridibundus individuals, alongside Bombina bombina, Hyla arborea, and from the reptiles only Natrix natrix was observed.

\section{DISCUSSION}

To our best knowledge, this is the first reconfirmation of the presence of Umbra krameri in the western part of the Danube floodplain of Romania, 21 years after, Bănărescu et al. (1995) suggested to verify its survival in this region. Moreover, this is the first record of the species from the Jiu River basin. Previous records from the region, close to Catana and Plosca (Bănărescu et al. 1995), are situated in the Danube floodplain, approximately $40 \mathrm{~km}$ south-west from the new one. Recently U. krameri was encountered in the eastern part of the Danube floodplain in this region, but south of the Danube, in Bulgaria, where it is very rare (Pehlivanov et al. 2011). Compared with previous Romanian studies, in which the species was not mentioned in southern Romania (Imecs and Nagy 2013, Năstase and Oțel 2016), our data indicate that U. krameri is still present in the region, but it is difficult to encounter.

The presence of Umbra krameri in the region of Banat is of even greater importance. There it was not mentioned previously (Bănărescu et al. 1995), although it is present southwards, in Serbia (Sekulic et al. 1998, Sekulić et al. 2013). This new locality is situated approximately $220 \mathrm{~km}$ from the north-western Romanian $U$. krameri populations and approximately $180 \mathrm{~km}$ from the ones in the Danube floodplain. It seems challenging to explain why U. krameri was not identified before in the region of Banat, because the habitat from Obad is appropriate for this species (Wanzenböck 1995, Wilhelm and Ardelean 2009, Sekulić et al. 2013, Pekárik et al. 2014). The Timiș River fish fauna was recently studied (Bănăduc et al. 2013), but the study focused on the main river course and not on the small channels and streams. Thus, it ignored habitats of U. krameri, which are situated at some distance for the main river courses (Pekárik et al. 2014). We used a net designed for capturing frogs, a net that proved efficient in habitats with rich vegetation (Telcean et al. 2014). These differences underline the importance of unconventional methods in fish studies (Telcean et al. 2014), which were found also important in other regions (Sekulić et al. 2013). Umbra krameri seems a good example. A similar explanation was used in the Banat region also in the case of an invasive fish species, Perccottus glenii Dybowski, 1877, which also used small aquatic habitats with rich vegetation (Covaciu-Marcov et al. 2017a). The same is true also in the Oltenia region.

The population in Oltenia is present in the wet areas of the Jiet River. It is a small rivulet parallel to the Jiu River and occupies a deserted riverbed of the Jiu River in the eastern parts of its lower floodplain (Ujvári 1972). Being a small watercourse it remained unaffected by a lot of human impacts that affected the Jiu River. Nevertheless, the region has been modified by humans and many areas are used as pastures. The habitat used by Umbra krameri is typical for this species, showing dense aquatic vegetation and slow flowing water (Wanzenböck 1995, Pekárik et al. 2014). It is probably permanent, being linked with the Jieț. The presence of a juvenile and an adult indicated that in the region a breeding population still exists, and in the area, there are probably other isolated populations of $U$. krameri. In the Jiu River floodplain, there are still large, relatively unaffected areas where the agriculture is less intensive. According to some literature (Kottelat and Freyhof 2007), U. krameri is considered absent from the region, but this seems to be not the result of 
the real disappearance of the species but the failure to search in specific habitats, which should be inspected. Nevertheless, its favourable habitats are reduced even in this area. As long as the agriculture will not become more intensive, the mudminnow occurrence seems safe. The presence of this rare species, highly protected by the Romanian legislation (Anonymous 2007) should increase the chance of its survival in the region, which is protected. But, although the lower reach of the Jiu River is included in a Natura 2000 protected areas, the specific area where U. krameri was found was left outside, and even more, it is not mentioned in the standard data form (Anonymous 2008).

In both regions, Umbra krameri is threatened by the same human activities, especially by agriculture and water management. The situation is worse in Banat, where the habitat is more deviated from natural conditions and surrounded by agricultural lands. Although just encountered, U. krameri may quickly disappear from the two regions, where the invasive fish Perccottus glenii is rapidly spreading (Copilaş-Ciocianu and Pârvulescu 2011, Covaciu-Marcov et al. 2011, 2017a, 2017b). Perccottus glenii is considered a threat for $U$. krameri (see Koščo et al. 2003, Reshetnikov 2013). Some localities with P. glenii are approximately only $20 \mathrm{~km}$ from Obad (CovaciuMarcov et al. 2011, 2017a). Umbra krameri is probably a relict in Banat, surviving in small and isolated habitats that remained after draining out the initial swamps (Burghelea et al. 2013). The population of $U$. krameri from Obad raises the problem of the biodiversity still hidden in the remaining, heavily affected wet areas within the plains of the Banat region. Compared with other regions from

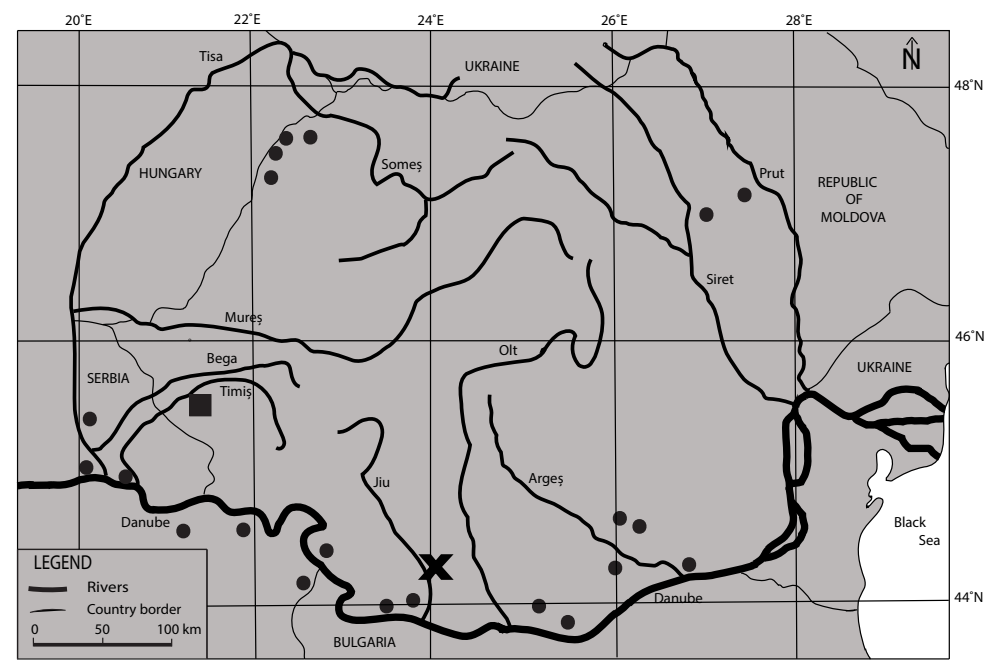

Fig. 1. Umbra krameri; new distribution records at Obad (Banat) $(\square)$, between Rojiste and Tâmburești (Oltenia) (X), and the previously known localities (O, from Bănărescu et al. 1995, Sekulić et al. 1998, Telcean et al. 2014)

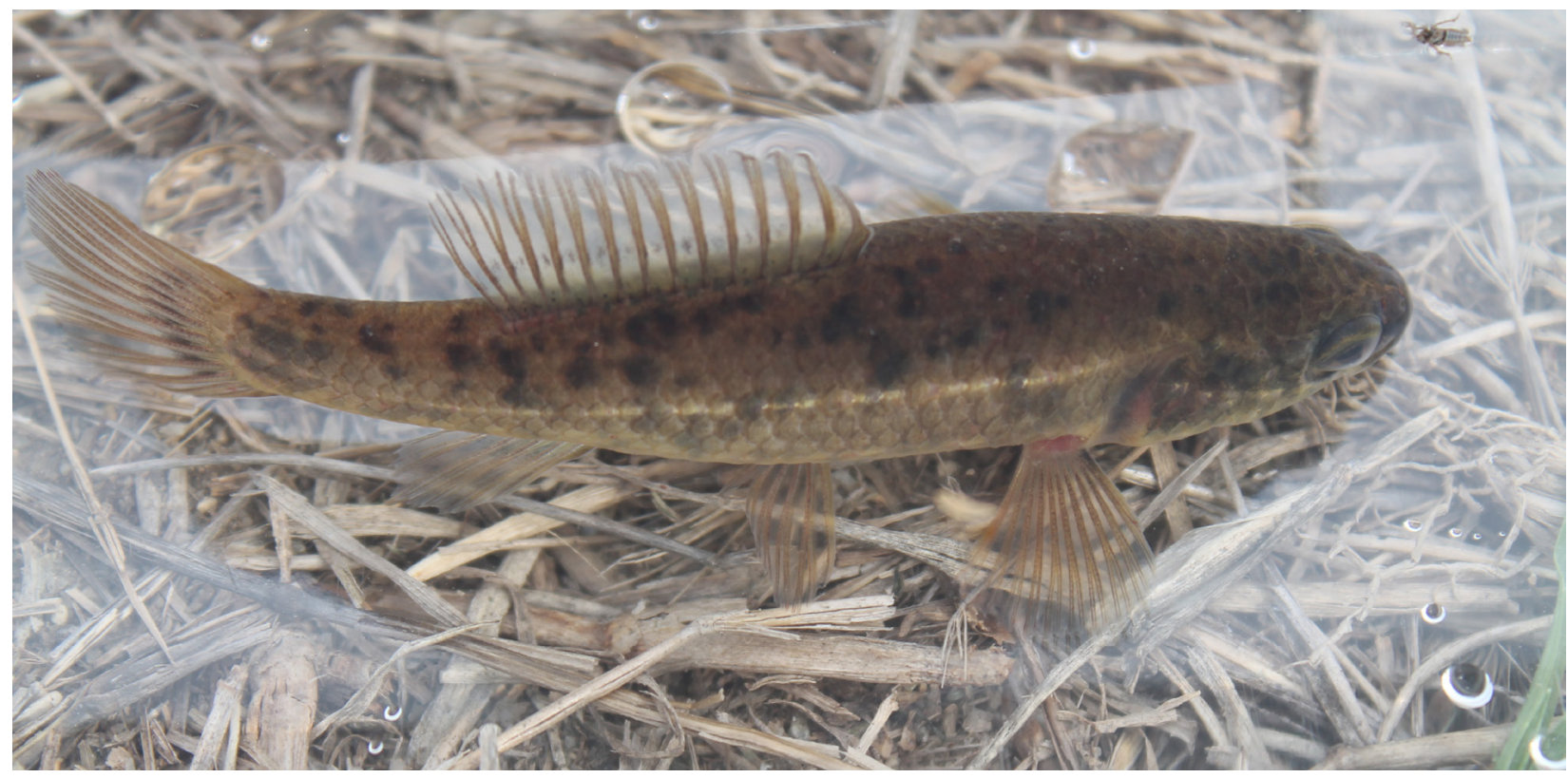

Fig. 2. Umbra krameri individual from the new distribution locality in south-western Romania 
western Romania, no relicts or species with zoogeographic particularities were mentioned in other groups from the Banat plains (Bogdan et al. 2013). Nevertheless, the discovery of Umbra krameri shows that at least in some groups, this may be a consequence of the absence of studies adequately performed.

\section{REFERENCES}

Anonymous 2007. O.U.G. nr. 57 / 2007 privind regimul ariilor naturale protejate, conservarea habitatelor naturale, a florei şi faunei sălbatice. [Law No. 57/2007 on the status of natural protected areas and the conservation of natural habitats, wild flora, and fauna]. Monitorul oficial I nr. 442/2007. [In Romanian.]

Anonymous 2008. Ordinul nr. 1964/2007 privind instituirea regimului de arie naturală protejată a siturilor de importanță comunitară, ca parte integrantă a rețelei ecologice europene Natura 2000 în România, Anexele nr. 6, ROSCI0045, Formularul Standard Natura 2000. [Law No. 1964/2007 on the establishment of protected area for sites of community interest, as an integral part of European ecological network Natura 2000 in Romania, Annexes No. 6, ROSCI0045, Natura 2000 Standard Data Form]. Monitorul Oficial I nr. 98/2008. [In Romanian.]

Bănăduc D., Stroilă V., Curtean-Bănăduc A. 2013. The fish fauna of the Timiş River (Banat, Romania). Transylvanian Review of Systematical and Ecological Research 15 (Special issue "The Timiş River Basin"): 145-172. DOI: $10.2478 /$ trser-2013-0040

Bănărescu P.M. 2005. Pisces (Peşti). [Pisces (Fishes)]. Pp. 215-255. In: Botnariuc N., Tatole V. (eds.) Cartea Roşie a Vertebratelor din România. [The Red Book of Vertebrates in Romania.] Editura Academiei Române, Bucharest, Romania. [In Romanian.]

Bănărescu P.M., Otel V., Wilhelm A. 1995. The present status of Umbra krameri Walbaum in Romania (Pisces, Umbridae). Annalen des Naturhistorischen Museums in Wien. Serie B für Botanik und Zoologie 97: 496-501.

Bogdan H.V., Ilieş D., Gaceu O. 2013. Conservation implications on present distribution of herpetofauna from plains areas of the Western Banat region, Romania. North-Western Journal of Zoology 9 (1): 172-177.

Burghelea B., Bănăduc D., Curtean-Bănăduc A. 2013. The Timiş River Basin (Banat, Romania) natural and anthropogenic elements. A study case-management challenges. Transylvanian Review of Systematical and Ecological Research 15 (Special issue "The Timiş River Basin”): 173-206. DOI: 10.2478/trser-2013-0041.

Copilaş-Ciocianu D., Pârvulescu L. 2011. New record of the Amur sleeper Perccottus glenii Dybowski, 1877 (Pisces: Odontobutidae), the first record in the Romanian Mureş River basin. Biharean Biologist 5 (1): 73-74.

Covaciu-Marcov S.-D., Ferenți S., Sas-Kovács I. 2017a. New records of Perccottus glenii Dybowski, 1877 from south-western Romania: Invasion in Timiş and
Aranca Rivers. South Western Journal of Horticulture, Biology and Environment 8 (2): 123-128.

Covaciu-Marcov S.-D., Sas-Kovács I., Cupşa D., Ferenţi S. 2017b. Perccottus glenii Dybowski, 1877 conquers new waters. First record in a Danube tributary from Oltenia region, southern Romania. Oltenia, Studii şi comunicări, Științele Naturii 33 (1): 123-126.

Covaciu-Marcov S.-D., Telcean I., Ferenţi S. 2011. Range extension of Perccottus glenii Dybowski, 1877 in western Romania, a new distribution route in the Danube River Basin? Journal of Applied Ichthyology 27 (1): 144-145. DOI: 10.1111/j.14390426.2010.01597.x

Imecs I., Nagy A.-A. 2013. Data concerning the fish fauna of the ROSCI0224 Scroviştea Natura 2000 site (Romania) and management measure proposals. Romanian Journal of Biology - Zoology 58 (2): 101114.

Koščo J., Lusk S., Halačka K., Lusková V. 2003. The expansion and occurrence of the Amur sleeper (Perccottus glenii) in eastern Slovakia. Folia Zoologica 52 (3): 329-336.

Kottelat M., Freyhof J. 2007. Handbook of European freshwater fishes. Kottelat, Cornol, Switzerland and Freyhof, Berlin, Germany.

Kuehne L.M., Olden J.D. 2014. Ecology and conservation of mudminnow species worldwide. Fisheries 39 (8): 341-351. DOI: 10.1080/03632415.2014.933318

Marić S., Snoj A., Sekulić N., Krpo-Ćetković J., Šanda R., Jojić V. 2015. Genetic and morphological variability of the European mudminnow Umbra krameri (Teleostei, Umbridae) in Serbia and in Bosnia and Herzegovina, a basis for future conservation activities. Journal of Fish Biology 86 (5): 1534-1548. DOI: $10.1111 / \mathrm{jfb} .12657$

Marić S., Stanković D., Wanzenböck J., Šanda R., Erős T., Takács P., Specziár A., Sekulić N., Bănăduc D., Ćaleta M., Trombitsky I., Galambos L., Sipos S., Snoj A. 2017. Phylogeography and population genetics of the European mudminnow (Umbra krameri) with a time-calibrated phylogeny for the family Umbridae. Hydrobiologia 792 (1): 151-168. DOI: 10.1007/ s10750-016-3051-9

Mândruț O. 2006. Mic Atlas de Geografie a României. [Small geography atlas of Romania.] Editura Corint, Bucharest. [In Romanian.]

Năstase A., Oțel V. 2016. Researches on the fish fauna in some SCIs Natura 2000 from Romania. AACL Bioflux 9 (3): 327-340.

Oțel V. 2007. Atlasul Peştilor din Rezervaţia Biosferei Delta Dunării. [Fish atlas from the Danube Delta Biosphere Reserve.] Editura Centrul de Informare Tehnologica Delta Dunării, Tulcea, Romania. [In Romanian.]

Pehlivanov L., Stefanov T., Mihov S., Biserkov V., Vassilev M., Apostolou A., Velkov B. 2011. Recent ichthyofauna in the wetlands along the Bulgarian section of the Danube. Scientific Annals of the Danube Delta Institute 17: 83-88. 
Pekárik L., Hajdú J., Koščo J. 2014. Identifying the key habitat characteristics of threatened European mudminnow (Umbra krameri, Walbaum 1792). Fundamental and Applied Limnology 184 (2): 151159. DOI: $10.1127 / 1863-9135 / 2014 / 0477$

Povž M. 1995. Threatened fishes of the world: Umbra krameri Walbaum, 1792 (Umbridae). Environmental Biology of Fishes 43 (3): 232. DOI: 10.1007/ BF00005854

Reshetnikov A.N. 2013. Spatio-temporal dynamics of the expansion of rotan Perccottus glenii from westUkrainian centre of distribution and consequences for European freshwater ecosystems. Aquatic Invasions 8 (2): 193-206. DOI: 10.3391/ai.2013.8.2.07

SekulicN.,BudakovL.,BrankovicD. 1998. Distributionof the European mudminnow Umbra krameri (Umbridae) in Serbia. Italian Journal of Zoology 65 (Suppl. 1): 381-382. DOI: 10.1080/11250009809386851

Sekulić N., Marić S., Galambos L., Radošević D., KrpoĆetković J. 2013. New distribution data and population structure of the European mudminnow Umbra krameri in Serbia and in Bosnia and Herzegovina. Journal of Fish Biology 83 (3): 659-666. DOI: 10.1111/jfb.12183

Takács P., Erős T., Specziár A., Sály P., Vitál Z., Ferincz Á., Molnár T., Szabolcsi Z., Biró P., Csoma E. 2015. Population genetic patterns of threatened European mudminnow (Umbra krameri Walbaum, 1792) in a fragmented landscape: Implications for conservation management. PLoS ONE 10 (9): e0138640. DOI: 10.1371/journal.pone.0138640

Tatár S., Bajomi B., Specziár A., Tóth B., Müllerné Trenovszki M., Urbányi B., Csányi B., Szekeres J., Müller T. 2017. Habitat establishment, captive breeding and conservation translocation to save threatened populations of the Vulnerable European mudminnow Umbra krameri. Oryx 51 (4): 718-729. DOI: 10.1017/S0030605316000533

Telcean I.C., Cupşa D., Sas-Kovács I., Cicort-Lucaciu A.-S., Covaciu-Marcov S.-D. 2014. Some data upon the fish fauna from Carei Plain natural protected area obtained with herpetological methods. North-Western Journal of Zoology 10 (Suppl. 1): S135-S140.

Ujvári I. 1972. Geografia apelor României. [The geography of the Romanian waters.] Editura Științifică, București, Romania. [In Romanian.]

Wanzenböck J. 1995. Current knowledge on the European mudminnow, Umbra krameri Walbaum, 1792 (Pisces, Umbridae). Annalen des Naturhistorischen Museums in Wien. Serie B für Botanik und Zoologie 97: 439449.

Wilhelm S., Ardelean G. 2009. Ţigănuşul (Umbra krameri) studiu monografic. [The European mudminnow (Umbra krameri) monographic study.] Editura Daya, Satu Mare, Romania. [In Romanian.]

Received: 9 February 2018

Accepted: 18 May 2018

Published electronically: 30 September 2018 
